\section{Optimizing Irrigation of Fresh Market Tomato Grown in the Mid-Atlantic United States}

\author{
Catherine S. Fleming ${ }^{1,4}$, Mark S. Reiter ${ }^{2}$, Joshua H. Freeman ${ }^{3}$, \\ and Rory Maguire ${ }^{1}$
}

ADDITIONAL INDEX WORDs. drip irrigation, polyethylene mulch, tensiometer, Virginia

SumMARY. Determining irrigation requirements for fresh market tomato (Solanum lycopersicum) production is essential to obtain optimum yields, cost-effective water use, and minimize nitrate leaching. The objective of this study was to determine the appropriate irrigation rate for polyethylene-mulched fresh market tomato grown in Virginia. This study investigated irrigation regimes by applying water based on evapotranspiration (ET) calculations in three spring and three fall seasons. Plants were grown using $0.0 \times \mathrm{ET}, 0.5 \times \mathrm{ET}, 1.0 \times \mathrm{ET}, 1.5 \times \mathrm{ET}$, and $2.0 \times \mathrm{ET}$. Additional irrigation treatments involved tensiometers installed at 12 -inch depth in the bed, programmed to irrigate at soil moisture set points of $-20,-40$, and $-60 \mathrm{kPa}$. Tensiometer treatments were able to irrigate up to nine times per day if soil moisture fell below the designated moisture set point. Measurements included fruit yield, plant and fruit nitrogen $(\mathrm{N})$ uptake, and inorganic soil nitrate- $\mathrm{N}\left(\mathrm{NO}_{3}-\mathrm{N}\right)$ at 0 to 10 -, 10 to 20 -, and 20 to 30 -inch depths. Overall, the $0.5 \times$ ET treatment provided optimum yields in all growing seasons except Spring 2010, which was unseasonably hot and dry. A tensiometer treatment $(-40 \mathrm{kPa})$ provided optimum yields in all growing seasons, and was able to adjust irrigation in a hot and dry season. Residual soil $\mathrm{NO}_{3}-\mathrm{N}$ at 0 to 10 inches generally exhibited an inverse relationship with yield; greater yields resulted in less residual soil $\mathrm{NO}_{3}-\mathrm{N}$. In most treatments throughout the duration of this study, plant $\mathrm{N}$ uptake + fruit $\mathrm{N}$ uptake accounted for most of the $\mathrm{N}$ fertilizer applied $(68 \%$ to $151 \%)$. In conclusion, an irrigation rate of $0.5 \times \mathrm{ET}$ and a tensiometer treatment $(-40 \mathrm{kPa})$ provided minimal irrigation inputs to obtain optimum marketable yields while also minimizing residual soil nitrate that may be prone to leaching after the season.

$\mathrm{T}$ omato is an extensively grown vegetable crop on the Eastern Shore of Virginia (Accomack and Northampton counties). In 2011, 4600 acres of commercial fresh market tomato were harvested in Virginia, with an estimated value of $\$ 47.5$ million [U.S. Department of Agriculture (USDA), 2013]. Commercial producers in the United States harvested a total of 94,210 acres of fresh market tomato plants with Virginia ranked third in harvested acreage after California

\footnotetext{
We would like to thank the funders of this project, Virginia Department of Agriculture Specialty Crop Competitive Grant Program, for helping to make this research possible. We would also like to thank the staff at the Virginia Tech Eastern Shore Agricultural Research and Extension Center in Painter, Virginia, for their help, hard work, and dedication to this project.

${ }^{1}$ Department of Crop and Soil Environmental Sciences, Virginia Tech, 330 Smyth Hall, Blacksburg, VA 24061

${ }^{2}$ Department of Crop and Soil Environmental Sciences, Virginia Tech, Eastern Shore Agricultural Research and Extension Center, 33446 Research Drive, Painter, VA 23420

${ }^{3}$ Department of Horticulture, University of Florida, North Florida Research \& Education Center, 155 Research Road, Quincy, FL 32351

${ }^{4}$ Corresponding author. Email: cathy@vt.edu.
}

and Florida [32,000 and 28,500 acres, respectively (USDA, 2013)]. In regards to value of production, Virginia ranked fourth behind Florida, CA, and North Carolina [ $\$ 435, \$ 259$, and $\$ 53$ million, respectively (USDA, 2013)]. With so many acres dedicated to tomato grown in close proximity to the Chesapeake Bay and tributaries leading to the bay, nitrate leaching and runoff are of great concern.

Drip irrigation combined with polyethylene mulch is a common practice for commercially grown fresh market tomato in the mid-Atlantic United States. Drip irrigation and polyethylene mulch systems reduce evaporation and therefore increase water use efficiency on coarse soils with low water-holding capacities, among many other benefits (Hochmuth et al., 2012; Zotarelli et al., 2009a). Coarse sandy soils have water-holding capacities of $8 \%$ to $15 \%$, while fine textured soils may have water-holding capacities over $40 \%$ (Locascio, 2005). With a lower water-holding capacity in coarse soils, proper irrigation is necessary to obtain optimum yield, uphold cost-effective water use, and reduce the propensity for dissolved nutrients to leach (Zotarelli et al., 2009b). Determining suitable timing and quantity to irrigate is essential for efficient crop production. Stanley and Clark (2004) suggested irrigating with frequent short durations using drip irrigation on soils with low waterholding capacities to reduce water loss.

A crop's water requirement is determined by the ET that takes place from the system. Evapotranspiration is a measurement of water loss from the cropping system that occurs through two processes: 1) evaporation from the soil surface and 2) transpiration from plant leaves; this amount directly relates to the plant's water need. Irrigation requirements are equal to the amount of water lost through ET minus water deposited through precipitation (Allen et al., 1998; Doorenbos and Pruitt, 1977). In situ measurements of actual soil moisture can also be used to determine when irrigation is needed. Smajstrla et al. (1997) discussed irrigation scheduling on sandy soils in Florida and suggested using a tensiometer

\begin{tabular}{llll}
\hline $\begin{array}{l}\text { Units } \\
\text { To convert U.S. to SI, } \\
\text { multiply by }\end{array}$ & U.S. unit & SI unit & $\begin{array}{l}\text { To convert SI to U.S., } \\
\text { multiply by }\end{array}$ \\
\hline 0.4047 & acre $(\mathrm{s})$ & $\mathrm{ha}$ & $2.471 \mathrm{l}$ \\
102.7902 & acre-inch(es) & $\mathrm{m}$ & 0.0097 \\
100 & bar & $\mathrm{kPa}$ & 0.01 \\
1 & cbar & $\mathrm{kPa}$ & 1 \\
0.3048 & $\mathrm{ft}$ & $\mathrm{m}$ & 3.2808 \\
9.3540 & gal/acre & $\mathrm{L} \cdot \mathrm{ha}^{-1}$ & 0.1069 \\
2.54 & inch(es) & $\mathrm{cm}$ & 0.3937 \\
25.4 & inch(es) & $\mathrm{mm}$ & 0.0394 \\
0.4536 & $\mathrm{lb}$ & $\mathrm{kg}$ & 2.2046 \\
1.1209 & $\mathrm{lb} / \mathrm{acre}$ & $\mathrm{kg} \cdot \mathrm{ha}^{-1}$ & 0.8922 \\
0.0254 & mil & $\mathrm{mm}$ & 39.3701 \\
1 & $\mathrm{ppm}$ & $\mathrm{mg} \cdot \mathrm{kg}^{-1}$ & 1 \\
1 & $\mathrm{ppm}$ & $\mathrm{mg} \cdot \mathrm{L}^{-1}$ & 1 \\
$\left({ }^{\circ} \mathrm{F}-32\right) \div 1.8$ & ${ }^{\circ} \mathrm{F}$ & ${ }^{\circ} \mathrm{C}$ & $\left({ }^{\circ} \mathrm{C} \times 1.8\right)+32$
\end{tabular}


that provided a direct measurement of soil matric potential at the installed depth. In addition to calculated ET that determined the amount to irrigate, a tensiometer can indicate when to irrigate.

A study performed by Locascio and Smajstrla (1996) examined calculated irrigation rates and tensiometerbased treatments and applied multiple rates of irrigation based on calculated pan-evaporation to polyethylenemulched tomato on a fine sandy soil near Gainesville, FL. They observed in dry years, quantities between $0.5 \times$ and $1.0 \times$ pan-evaporation produced maximum yields. Pan-evaporation is a measurement of the rate of water lost via evaporation from a U.S. Weather Service Class A pan. Maximum production was obtained by using a tensiometer scheduled to initiate irrigation at $-10 \mathrm{kPa}$, with a water output of $0.35 \times$ pan-evaporation. Soil samples $(0$ to $15 \mathrm{~cm})$ taken throughout the growing seasons showed that in treatments receiving irrigation, water quantity did not influence water extractable nitrogen [nitrate- $\mathrm{N}+$ ammonium- $\mathrm{N}$ $\left.\left(\mathrm{NH}_{4}-\mathrm{N}\right)\right]$. However, a 0 -water treatment did result in greater water extractable $\mathrm{N}$ than all irrigated treatments, likely due to lesser yields in two out of three growing seasons. The tensiometer treatment extractable soil $\mathrm{N}$ values were similar to the average of all irrigated treatments. Marketable yield in the tensiometer treatment was not significantly different from $0.75 \times$ panevaporation yield in all three growing seasons.

Evapotranspiration for a specific crop $\left(\mathrm{ET}_{\mathrm{c}}\right)$ is calculated by multiplying a reference ET $\left(\mathrm{ET}_{\mathrm{o}}\right)$ by the appropriate crop coefficient $\left(\mathrm{K}_{\mathrm{c}}\right)$ :

$$
\mathrm{ET}_{\mathrm{c}}=\mathrm{ET}_{\mathrm{o}} \times \mathrm{K}_{\mathrm{c}}
$$

Reference ET is based on a hypothetical grass surface that is only affected by climactic conditions; soil conditions are not considered. The Food and Agriculture Organization of the United Nations (FAO) suggested the use of the Hargreaves equation:

$$
\begin{aligned}
\mathrm{ET}_{\mathrm{o}}= & 0.0023 \times\left(\mathrm{T}_{\text {mean }}+17.8\right) \\
& \times\left(\mathrm{T}_{\max }-\mathrm{T}_{\text {min }}\right)^{0.5} \times \mathrm{R}_{\mathrm{a}}
\end{aligned}
$$

to calculate the hypothetical grass surface $\mathrm{ET}_{\mathrm{o}}$, where $\mathrm{ET}_{\mathrm{o}}=$ reference $\mathrm{ET}$, $\mathrm{T}_{\text {mean }}=$ mean temperature (degrees
Celsius), $\mathrm{T}_{\max }=$ maximum temperature (degrees Celsius), $\mathrm{T}_{\text {min }}=$ minimum temperature (degrees Celsius), and $\mathrm{R}_{\mathrm{a}}=$ extraterrestrial solar radiation (millimeters per day) (Allen et al., 1998)

The use of drip irrigation and polyethylene mulch decreases evaporation from the field system and therefore decreases the $\mathrm{K}_{\mathrm{c}}$ (Allen et al., 1998; Amayreh and Al-Abed, 2005). These values are associated with increasing canopy growth and associated increased transpiration. $\mathrm{K}_{\mathrm{c}}$ is a unitless ratio of $\mathrm{ET}_{c} / \mathrm{ET}_{\mathrm{o}}$ that can be found in several FAO publications (Allen et al., 1998; Doorenbos and Pruitt, 1977) for vegetables, forages, fruit trees, and other crops. The value varies based on crop, growth stage, and management practices (Smajstrla et al., 1997). Most crop coefficients range from 0.5 to 1.2 with larger values during midseason $\left(\mathrm{K}_{\mathrm{c} \text { mid }}\right)$ growth as water requirements are increased, and lower values during initial $\left(K_{c}\right.$ ini $)$ and late-season $\left(K_{c}\right.$ end $)$ growth as water requirements decrease. Haddadin and Ghawi (1983) studied the effect of polyethylene mulch on field-grown tomato on sandy loam soil in the Jordan Valley of Israel and found that the use of black plastic mulch significantly increased yield and water use efficiency. The FAO reported that Haddadin and Ghawi's (1983) research found a reduction of $\mathrm{K}_{\mathrm{c}}$ by $35 \%$ for tomato when using polyethylene mulch with drip irrigation (Allen et al., 1998). Amayreh and Al-Abed (2005) found similar results with a $36 \%$ reduction in $\mathrm{K}_{\mathrm{c}}$ over the entire growing season for polyethylene mulched, drip-irrigated tomato grown on a silty clay soil in the Jordan Valley. More specifically, Amayreh and Al-Abed (2005) found a $35 \%$ reduction of $\mathrm{K}_{\mathrm{c}}$ in the development stage (initial and crop development stages), a $31 \%$ reduction of $\mathrm{K}_{\mathrm{c} \text { mid }}$, and a $40 \%$ reduction of $\mathrm{K}_{\mathrm{c} \text { end. Reducing }} \mathrm{K}_{\mathrm{c}}$ decreases the calculated volume of water to apply to crops and may reduce nutrient leaching attributable to excess irrigation.

If nutrients leach below the effective root zone, they will not be absorbed by the plant and are lost from the production system, reducing fertilizer use efficiency. Machado and Oliveira (2005) reported that rooting depth of tomato in sandy soil was independent of three different water regimes and three different drip irrigation depths. Zotarelli et al. (2009b), observed tomato root systems under several irrigation treatments on sandy soil near Citra, FL. Root distribution patterns showed that independent of irrigation treatment, root length density concentrated around drip tape emitters. Zotarelli et al. (2009b), Oliveira et al. (1996), and Machado and Oliveira (2005) agree that the majority of tomato roots are concentrated in the upper $40 \mathrm{~cm}$ of the soil profile. Therefore, nutrient movement below $40 \mathrm{~cm}$ has exited the effective root system of tomato, and consequently, the production system.

Ideally, an optimal irrigation regime limits the amount of fertilizer leached below the root zone and conserves irrigation water usage, while providing optimum marketable yields. The objective of this study was to determine an optimal irrigation regime for polyethylene-mulched fresh market tomato grown on a sandy loam soil in the mid-Atlantic United States.

\section{Materials and methods}

This study was established in the spring and fall seasons of 2009, 2010, and 2011 (six site seasons) on a Bojac sandy loam (coarse-loamy, mixed, semiactive, thermic Typic Hapludults) (USDA, 2002) at the Virginia Tech Eastern Shore Agricultural Research and Extension Center in Painter, VA (lat. $37.59^{\circ} \mathrm{N}$, long. $75.77^{\circ} \mathrm{W}$ ). Bojac sandy loam has $\approx 59 \%$ sand, $30 \%$ silt, and $11 \%$ clay in the Ap horizon (0 to 18 inches). The soil was conventionally tilled, and 8 -inch raised beds were constructed on $6-\mathrm{ft}$ centers. In a single pass, beds were fumigated with methyl bromide and chloropicrin $[67: 33(\mathrm{w} / \mathrm{w})]$ at the rate of $300 \mathrm{lb} / \mathrm{acre}$, and 1.25 -milthick polyethylene mulch was applied over the bed. Under the mulch, drip tubing was deployed (Aqua-Traxx; Toro, Riverside, CA) with emitters spaced 12 inches apart and a delivery rate of $5.6 \mathrm{~L} / 100 \mathrm{~m}$ per minute at 0.55 bar was placed 3 to 4 inches from the bed center. Four to 5-week-old tomato seedlings ('BHN 602'; BHN Seed, Immokalee, FL) were transplanted on 18-inch in-row spacings, resulting in a plant population density of $\approx 4840$ plants/acre. Tomato seedlings were transplanted in $40-\mathrm{ft}$ single row plots on 20 May 2009, 21 May 
2010, and 25 May 2011, for the spring season and on 17 July 2009, 13 July 2010 , and 28 July 2011 , for the fall season. All other production practices were conducted according to Wilson et al. (2012).

Calculating ET. We calculated $\mathrm{ET}_{\mathrm{c}}$ by multiplying $\mathrm{K}_{\mathrm{c}}$ by $\mathrm{ET}_{\mathrm{o}}(\mathrm{Eq}$. [1]). Described by Allen et al. (1998), $\mathrm{ET}_{\mathrm{o}}$ was determined using the Hargreaves equation via temperature and extraterrestrial solar radiation. A 1971-2000 Monthly Climate Summary from the Southeast Regional Climate Center (2007) for Painter, VA (lat. $37.35^{\circ} \mathrm{N}$, long. $75.49^{\circ} \mathrm{W}$ ) provided monthly minimum and maximum temperature values. Extraterrestrial solar radiation for Painter, VA, was found from Table 2.6 of Allen et al. (1998) by using an estimated latitude of $38^{\circ} \mathrm{N}$.

To calculate $\mathrm{ET}_{\mathrm{c}}$ for different growth stages, $\mathrm{K}_{\mathrm{c}}$ was interpolated from Doorenbos and Pruitt (1977) and Allen et al. (1998). The $\mathrm{K}_{\mathrm{c}}$ for tomato was estimated at 0.60 for $\mathrm{K}_{\mathrm{c} \text { ini }}$ (Allen et al., 1998), and $\mathrm{K}_{\mathrm{c} \text { mid }}$ and $\mathrm{K}_{\mathrm{c}}$ end values of 1.05 and 0.60 (Doorenbos and Pruitt, 1977), respectively. The $\mathrm{K}_{\mathrm{c}}$ value during the crop development $\left(\mathrm{K}_{\mathrm{c} C \mathrm{D}}\right)$ stage was estimated to be 0.83 , an average of the values used for $K_{c \text { ini }}$ and $K_{c \text { mid. }}$. The progression of $K_{c}$ throughout the growing season was $\mathrm{K}_{\mathrm{c} \text { ini }}, \mathrm{K}_{\mathrm{c}} \mathrm{CD}$, $\mathrm{K}_{\mathrm{c} \text { mid }}$, and finally $\mathrm{K}_{\mathrm{c} \text { end. }}$. Crop growth stage was based on physiological maturity of the plant to account for varying growth advancements per season (Allen et al., 1998). Crop coefficient values were reduced accordingly in calculating $\mathrm{ET}_{\mathfrak{c}}$ over the growing season because of the use of polyethylene mulch. Crop coefficients during initial growth stage, crop development stage, and midseason stage were reduced by $35 \%, 35 \%$, and $31 \%$, respectively (Amayreh and Al-Abed, 2005).

Calculating irrigation. Irrigation needed for a crop is $\mathrm{ET}_{\mathrm{c}}$ minus precipitation (Allen et al., 1998; Doorenbos and Pruitt, 1977). Longterm average precipitation data were used from the Southeast Regional Climate Center (2007). A 1971-2000 Monthly Climate Summary for Painter, VA, was used for average monthly total precipitation estimates. Historical rainfall data were used to calculate average daily precipitation and subtracted from $\mathrm{ET}_{\mathrm{c}}$ to determine daily irrigation for respective month and growth stages of the crop. Irrigation calculated by subtracting precipitation from $\mathrm{ET}_{\mathrm{c}}$, as defined by Doorenbos and Pruitt (1977) and Allen et al. (1998), was labeled as treatment " $1.0 \times \mathrm{ET}$ " in this study.

IRRIGATION TREATMENTS. Irrigation treatments were set using automatic timers (Hunter Smart Valve Controller, San Marcos, CA). The total calculated daily watering time per treatment was halved to irrigate twice a day, and applied $7 \mathrm{~d}$ per week, to deliver $0.0 \times \mathrm{ET}, 0.5 \times \mathrm{ET}, 1.0 \times \mathrm{ET}, 1.5 \times$ $\mathrm{ET}$, and $2.0 \times \mathrm{ET}$. Irrigation for the tensiometer treatments was triggered automatically with a wired tensiometer (model RA; Irrometer, Riverside, $\mathrm{CA}$ ) installed in the active root zone (12-inch depth). One wired tensiometer was used to trigger irrigation for all four replications. Several other tensiometers were installed in treatments to verify the wired tensiometer readings in the respective treatments. Irrigation for the tensiometer treatments (Tens-20, Tens-40, and Tens$60)$ initiated after the tensiometer's reading raised above preset values of $-20,-40$, or $-60 \mathrm{kPa}$, respectively, based on the treatment (only a -40 $\mathrm{kPa}$ value was used in 2009). An automatic timer wired into the tensiometer/irrigation system switched irrigation on for a maximum possibility of nine times per day. Each of the nine possible irrigation periods were set for the duration of time calculated for daily $0.5 \times \mathrm{ET}$. This gave the possibility of the automatic tensiometer system to water between $0.0 \times \mathrm{ET}$ and $4.5 \times \mathrm{ET}$.

Irrigation outputs were measured by cumulative water application on four replications for each treatment. A water meter (C700; Elster AMCO Water, Ocala, FL) was installed for each treatment, and cumulative water output was recorded weekly throughout the season.

The overall experimental design was a randomized complete block design that had treatments replicated four times, giving a total plot combination of 20 plots in Spring 2009 $(0.5 \times \mathrm{ET}, 1.0 \times \mathrm{ET}, 1.5 \times \mathrm{ET}, 2.0 \times$ ET, and Tens-40), 24 plots in Fall $2009(0.0 \times \mathrm{ET}, 0.5 \times \mathrm{ET}, 1.0 \times \mathrm{ET}$, $1.5 \times \mathrm{ET}, 2.0 \times \mathrm{ET}$, and Tens -40$)$, and 32 plots $(0.0 \times \mathrm{ET}, 0.5 \times \mathrm{ET}, 1.0 \times$ ET, $1.5 \times$ ET, $2.0 \times$ ET, Tens-20, Tens-40, and Tens-60) in both spring and fall seasons of 2010 and 2011 .
Fertilizer application. A total of $200 \mathrm{lb} /$ acre $\mathrm{N}$ was applied over the growing season. A preplant rate of $86 \mathrm{lb}$ /acre $\mathrm{N}$ using ammonium nitrate $(34 \mathrm{~N}-0 \mathrm{P}-0 \mathrm{~K})$ was incorporated into the plant beds using a rotary tiller before laying polyethylene mulch. The remaining $\mathrm{N}(114 \mathrm{lb} /$ acre $\mathrm{N})$ was applied using liquid urea-ammonium nitrate $(32 \mathrm{~N}-0 \mathrm{P}-0 \mathrm{~K})$ through biweekly fertigation throughout the growing season during prescheduled irrigation events. Nitrogen rates used in fertigation increased as the growing season progressed to match plant $\mathrm{N}$ uptake (Wilson et al., 2012). Fertigated $\mathrm{N}$ was applied at $0.50,0.70$, $1.00,1.50,2.20$, and $2.43 \mathrm{lb} / \mathrm{d} \mathrm{N}$ for time periods $0-14,15-28,29-42$, $43-56,57-77$, and 78-98 d after transplanting, respectively. All treatments received the same amount of $\mathrm{N}$ fertilizer before planting and throughout biweekly fertigation. Additionally, phosphorus and potassium fertilizers were applied equally to all treatments based on soil test results (Maguire and Heckendorn, 2011).

Petiole sap $\mathrm{NO}_{3}-\mathrm{N}$. Petiole sap $\mathrm{NO}_{3}-\mathrm{N}$ tests were performed when fruit were $\approx 2$ inches in diameter. Petioles were collected from six plants per plot from the upper most fully expanded leaf (Hochmuth, 1994; Ozores-Hampton et al., 2012) between 10:00 AM and 12:00 PM. The sap of all six petioles was combined, and $\mathrm{NO}_{3}-\mathrm{N}$ concentrations were found using a Cardy meter (Spectrum Technologies, Plainfield, IL).

YIELD. Yield was calculated by harvesting mature green fruit two to three times, depending on the season, which is the standard agronomic practice. Fruit were separated by size according to USDA standards (USDA, 1991) and weighed. Medium, large, and extralarge fruit weights were combined to determine marketable yield.

Postharvest SAMpling. After harvest termination, plant, fruit, and soil samples were collected. One plant per plot was collected, dried, and weighed to estimate total aboveground biomass. Plant samples were ground and analyzed for total $\mathrm{N}$ via combustion (Bremner, 1996) (vario EL cube; Elementar Americas, Mt. Laurel, NJ) to determine plant $\mathrm{N}$ concentrations. $\mathrm{Ni}-$ trogen concentration in the plant material was subsequently multiplied by plant biomass to determine total aboveground $\mathrm{N}$ uptake in the plant. 
Five fruit from each plot were collected, dried, ground, and analyzed for total $\mathrm{N}$ via combustion (vario $\mathrm{EL}$ cube) to determine fruit $\mathrm{N}$ concentration. Nitrogen concentrations in the fruit material were multiplied by fruit biomass to determine total aboveground $\mathrm{N}$ uptake in the fruit. Fruit were assumed to contain $94 \%$ water (Angelini and Magnifico, 2010). Therefore, total yield was multiplied by $6 \%$ to determine fruit biomass. Plant and fruit $\mathrm{N}$ concentrations multiplied by total aboveground biomass and total fruit yield, respectively, determined total system (plant + fruit) $\mathrm{N}$ uptake. $\mathrm{Ni}-$ trogen use efficiency of applied fertilizer (FNUE) was calculated as total system $\mathrm{N}$ uptake divided by total $\mathrm{N}$ applied via fertilizer, multiplied by 100.

Soil samples from 0 to $10-, 10$ to $20-$, and 20 to 30 -inch depths were collected. For each depth, two cores were taken on the side of the bed opposite of the drip tape, and four cores on the side of the bed with the drip tape; two between the drip tape and the edge of the bed and two between the drip tape and the center of the bed. Soil samples were air dried and ground. Soils were extracted with $2 \mathrm{M}$ potassium chloride $(\mathrm{KCl})$ at a 1:10 soil:2 $\mathrm{M} \mathrm{KCl}$ ratio, shaken for $\mathrm{l} \mathrm{h}$, and filtered (Mulvaney, 1996). Extracts were analyzed within $24 \mathrm{~h}$ for nitrate- $\mathrm{N}+$ nitrite- $\mathrm{N}$ colormetrically using a continuous flow analyzer (Lachat QuickChem 8500; Hach Co., Loveland, CO).

STATistics. Statistical analysis was conducted with JMP (version 9; SAS Institute, Cary, NC). An analysis

Table 1. Season-long irrigation for fresh market tomato grown on a Bojac sandy loam soil in 2009, 2010 , and 2011.

\begin{tabular}{|c|c|c|c|c|c|c|}
\hline \multirow[b]{3}{*}{ Treatment $^{\mathrm{z}}$} & \multicolumn{2}{|c|}{2009} & \multicolumn{2}{|c|}{2010} & \multicolumn{2}{|c|}{2011} \\
\hline & Spring & Fally & Spring & Fall & Spring & Fall \\
\hline & \multicolumn{6}{|c|}{ Irrigation (acre-inches) ${ }^{\mathrm{x}}$} \\
\hline $0.0 \times \mathrm{ET}$ & - & - & 1.4 & 0.5 & 0.4 & 0.4 \\
\hline $0.5 \times \mathrm{ET}$ & 6.5 & - & 5.7 & 2.5 & 5.5 & 3.1 \\
\hline $1.0 \times \mathrm{ET}$ & 12.2 & - & 9.9 & 5.4 & 12.1 & 3.9 \\
\hline $1.5 \times \mathrm{ET}$ & 16.3 & - & 17.6 & 7.8 & 12.8 & 5.7 \\
\hline $2.0 \times \mathrm{ET}$ & - & - & 17.1 & 7.6 & 16.0 & 5.7 \\
\hline Tens-20 & - & - & 5.7 & 10.7 & 14.0 & 3.5 \\
\hline Tens-40 & - & - & 17.3 & 5.0 & 9.9 & 3.8 \\
\hline Tens-60 & - & - & 3.9 & 13.9 & 9.5 & 1.8 \\
\hline Season length $(\mathrm{d})^{\mathrm{w}}$ & 82 & 89 & 80 & 80 & 79 & 109 \\
\hline
\end{tabular}

${ }^{2} \mathrm{ET}=$ evapotranspiration; Tens $=$ tensiometer treatments set at $-20,-40$, and $-60 \mathrm{kPa}$, respectively; $1 \mathrm{kPa}=1 \mathrm{cbar}$. "Readings not available for Fall 2009 season.

${ }^{x} 1$ acre-inch $=102.7902 \mathrm{~m}^{3}$.

"Days from transplant to final harvest.

of variance was performed and if significance was present $(P<0.10)$, separation of means was conducted using Student's $t$ least significant difference (LSD) values established at alpha $=0.10\left(\mathrm{LSD}_{0.10}\right)$. Season was significant for all data sets; therefore, all data were analyzed individually by season.

In Spring 2009, treatments $2.0 \times$ ET and the tensiometer treatment (Tens-40) encountered excessive pressure in the drip tubing and were inflicted with large leaks in the plots. Therefore, these treatments were removed from statistical analysis due to the confounding circumstances.

\section{Results and discussion}

IrRIgation RATES. Season-long irrigation and season length can be seen in Table 1. Readings for Fall 2009 were not available. Treatment $0.0 \times$ ET applied between 0.4 and 1.4 acre-inches of water through fertigation practices. Irrigation rates in calculated ET treatments varied between seasons because of physiological maturity progress of the plants and length of season.

Tensiometer treatments did not apply water as we expected (Tens-20 > Tens-40 > Tens-60). Many seasonlong adjustments needed to be made to accommodate the liquid in the tensiometer and ensure it did not dry out. Additionally, the wetting fronts from the drip tape emitters greatly impacted the necessary placement of the tensiometers in the bed and subsequent readings. Because of the disturbance of the soil when creating beds, soil structure and soil pores are altered, and therefore, the wetting front may vary. Overall, we believe the use of tensiometers in drip-irrigated fresh market tomato fields provides essential data on soil matric potential and can indicate when irrigation is needed. Data are included for all tensiometer treatments; however, using wired tensiometers to autoinitiate drip irrigation warrants further research.

YIELD. In Spring 2009, $0.5 \times$ ET and $1.0 \times$ ET yielded significantly more marketable fruit than $1.5 \times \mathrm{ET}$ $(63,331 ; 60,663$; and $44,153 \mathrm{lb} /$ acre marketable fruit, respectively) (Table $2)$. In Fall 2009 , Tens- 40 yielded similar to $0.5 \times$ ET $(44,686$ and $39,549 \mathrm{lb} /$ acre marketable fruit, respectively). However, out of the calculated irrigation treatments, $0.5 \times$ ET was similar to $1.0 \times \mathrm{ET}$ and $1.5 \times$ ET and greater yielding than $0.0 \times \mathrm{ET}$ and $2.0 \times \mathrm{ET}$.

In Spring 2010, $1.5 \times$ ET, $2.0 \times$ ET, and Tens -40 produced the greatest yields with 48,$188 ; 41,364$; and $42,496 \mathrm{lb} /$ acre marketable fruit, respectively (Table 2). $0.0 \times \mathrm{ET}$ resulted in significant yield loss, producing significantly less marketable yield than every other treatment. The Spring 2010 season was hotter and had less cumulative precipitation in May, June, and July than 2009, 2011 , and the 30 -year average (Fig. 1). Because of the unseasonably hot dry season, it was expected that higher calculated ET treatments would result in greater yields. In Spring 2010, the higher calculated irrigation treatments $(1.5 \times$ ET and $2.0 \times \mathrm{ET})$ were not significantly different from the Tens40 treatment, showing that the use of a tensiometer set at $-40 \mathrm{kPa}$ might protect yields in hotter and dryer growing seasons compared with calculated ET values. In a sandy loam, soil is at field capacity at -10 to $-20 \mathrm{kPa}$ and at -40 to $-60 \mathrm{kPa}, 50 \%$ of available water is depleted (Wilson et al., 2012). Treatments $1.5 \times$ ET, $2.0 \times$ ET, and Tens-40 applied similar amounts of irrigation in Spring 2010 (Table 1). In Fall 2010, there were no significant differences between treatments and average yield was 29,318 $\mathrm{lb} /$ acre marketable fruit.

In Spring 2011, $0.0 \times$ ET produced significantly less marketable fruit than every other treatment. There were no other significant differences in Spring 2011 between other irrigation treatments. In Fall 2011, 
Table 2. Marketable yield for fresh market tomato grown on a Bojac sandy loam soil in 2009, 2010, and 2011.

\begin{tabular}{|c|c|c|c|c|c|c|}
\hline \multirow[b]{3}{*}{ Treatment $^{\mathrm{z}}$} & \multicolumn{2}{|c|}{2009} & \multicolumn{2}{|c|}{2010} & \multicolumn{2}{|c|}{2011} \\
\hline & Spring & Fall & Spring & Fall & Spring & Fall \\
\hline & \multicolumn{6}{|c|}{ Marketable yield (lb/acre) ${ }^{\mathrm{y}}$} \\
\hline $0.0 \times \mathrm{ET}$ & - & $28,979 \mathrm{c}$ & $2,094 \mathrm{f}$ & $31,998 \mathrm{NS}$ & $22,888 \mathrm{~b}$ & $29,640 \mathrm{NS}$ \\
\hline $0.5 \times \mathrm{ET}$ & $63,331 a^{x}$ & $39,549 \mathrm{ab}$ & $20,110 \mathrm{e}$ & 36,500 & 55,938 a & 26,650 \\
\hline $1.0 \times \mathrm{ET}$ & $60,663 a$ & $33,505 \mathrm{bc}$ & $29,306 \mathrm{~cd}$ & 26,572 & $50,312 \mathrm{a}$ & 24,718 \\
\hline $1.5 \times \mathrm{ET}$ & $44,153 \mathrm{~b}$ & $36,185 \mathrm{bc}$ & 48,188 a & 24,309 & 56,596 a & 26,347 \\
\hline $2.0 \times \mathrm{ET}$ & - & $31,903 \mathrm{c}$ & $41,364 \mathrm{ab}$ & 23,819 & 49,979 a & 22,427 \\
\hline Tens-20 & - & - & $34,914 \mathrm{bc}$ & 31,563 & $62,243 \mathrm{a}$ & 30,024 \\
\hline Tens-40 & - & $44,686 a$ & $42,496 \mathrm{ab}$ & 28,629 & $56,168 \mathrm{a}$ & 23,809 \\
\hline Tens-60 & - & - & $27,098 \mathrm{de}$ & 31,158 & $54,112 \mathrm{a}$ & 28,790 \\
\hline$P$ value & 0.01 & 0.02 & $<0.01$ & 0.16 & 0.04 & 0.18 \\
\hline
\end{tabular}

${ }^{2} \mathrm{ET}=$ evapotranspiration; Tens $=$ tensiometer treatments set at $-20,-40$, and $-60 \mathrm{kPa}$, respectively; $1 \mathrm{kPa}=1 \mathrm{cbar}$. ${ }^{\mathrm{y}} \mathrm{l} \mathrm{lb} / \mathrm{acre}=1.1209 \mathrm{~kg} \cdot \mathrm{ha}^{-1}$.

'Means followed by the same letter, within column, are not significantly different $(P<0.10)$ by Student's $t$ least significant difference test; $\mathrm{NS}=$ not significantly different.

there were no significant differences between treatments and yields averaged $26,55 \mathrm{llb} /$ acre marketable fruit.

Overall, marketable yields for all treatments (except $0.0 \times \mathrm{ET}$ and
$0.5 \times$ ET in Spring 2010) were greater than average Virginia fresh market tomato production for 2009,2010 , and $2011 \quad[30,000 ; 21,000 ;$ and $22,000 \mathrm{lb} /$ acre fruit, respectively
(USDA, 2013)]. Even the $0.0 \times \mathrm{ET}$ treatment resulted in yields close to the Virginia averages (besides Spring 2010), likely due to above average June rains in 2009 and 2011 (Fig. 1), and generally cooler and wetter conditions in the fall season. However, weather factors including temperature and rainfall influenced yields in several calculated irrigation treatments, as seen in Spring 2010. In an unseasonably hot and dry growing season, calculating ET via historical averages will not supply sufficient irrigation for optimum yields. Locascio and Smajstrla (1996) saw in very dry seasons, a 0 -irrigation treatment $(0.0 \times \mathrm{ET})$ resulted in poor plant growth and water application to subsequent treatments significantly increased fruit yield. This is similar to our results in Spring 2010, which was very dry. Although yield in $0.5 \times \mathrm{ET}$ was significantly less than higher calculated ET irrigation rates $(1.5 \times \mathrm{ET}$
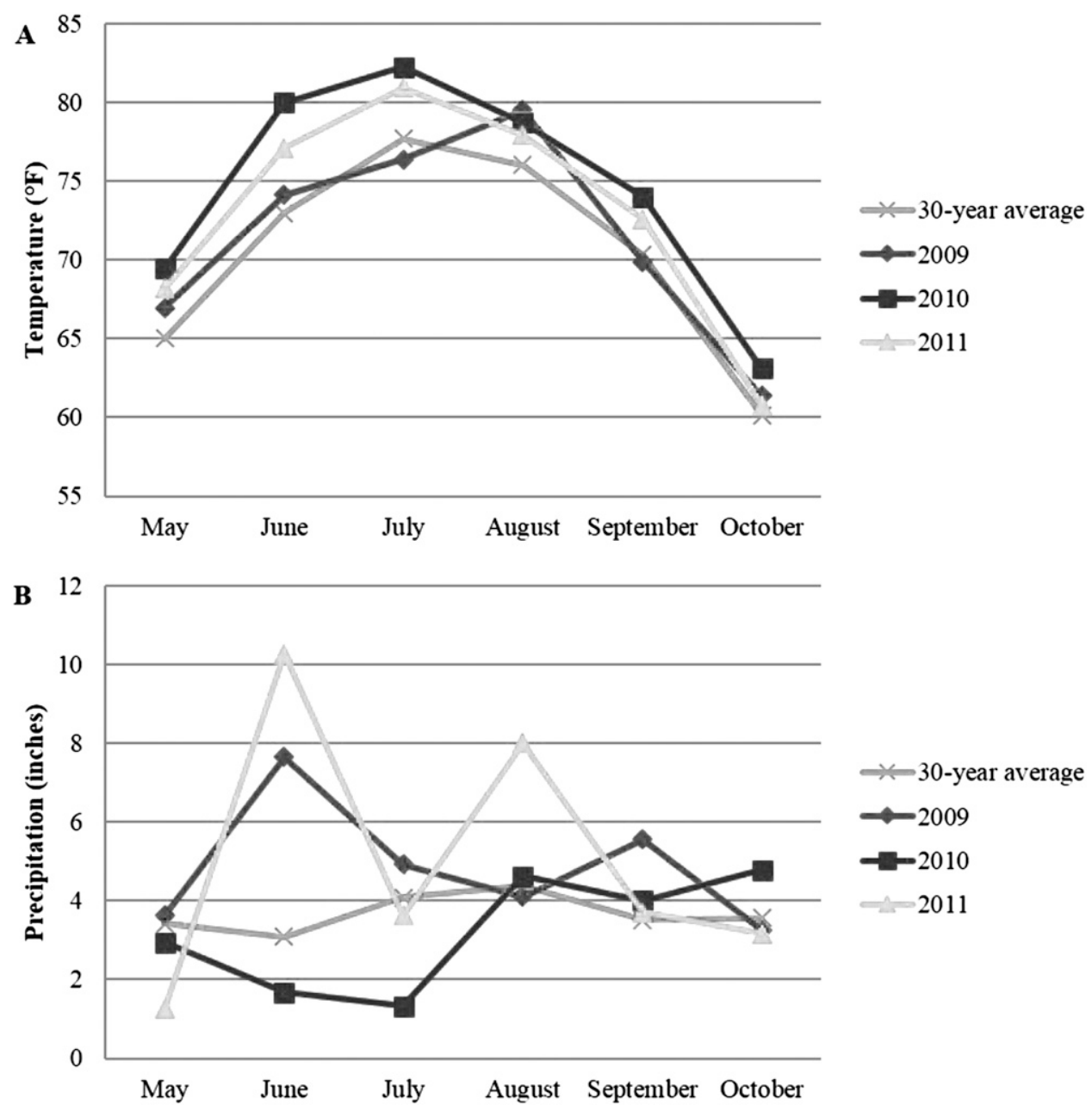

Fig. 1. Temperature (A) and precipitation (B) from Painter, VA during growing seasons of 2009, 2010, and 2011; 30-year averages provided by Southeast Regional Climate Center $(2007) ;\left({ }^{\circ} \mathrm{F}-32\right) \div 1.8={ }^{\circ} \mathrm{C}, 1 \mathrm{inch}=2.54 \mathrm{~cm}$. 
was greatest yielding in Spring 2010), a significant increase in yield was observed between $0.0 \times \mathrm{ET}$ and $0.5 \times \mathrm{ET}$. Additionally, while $0.5 \times$ ET in Spring 2010 produced yields near the average yield for Virginia in $2010(20,110$ and $21,015 \mathrm{lb} /$ acre fruit, respectively) irrigation was a limiting factor on yield as $1.0 \times$ ET resulted in significantly greater yields than $0.5 \times \mathrm{ET}$.

In Spring seasons, treatment $1.0 \times$ ET applied $\approx 0.23$ inch of water per day at season peak. Peak water applications for treatment $1.0 \times \mathrm{ET}$ in fall seasons were 0.13 inch per day. Less irrigation was needed in fall seasons because of milder temperatures and greater average rainfall. The lack of significant differences between treatments in Fall 2010 and Fall 2011 coincides with findings in Locascio and Smajstrla (1996) where marketable yield was unaffected by water application in a season with greater rainfall (averaging 1.3 inches/week) than other seasons, similar to Fall conditions in Virginia.

Incorporating daily weather readings into ET calculations would be beneficial in unseasonable growing conditions. However, producers would be reluctant to continuously vary their irrigation regimes and change irrigation controllers. An alternative to daily ET calculations is to use a tensiometer to monitor soil moisture (Coolong et al., 2011). Our expectation was for $1.0 \times$ ET to provide the optimal rate of irrigation to polyethylene mulched, drip-irrigated fresh market tomato plants grown in Painter, VA; as ET was calculated and $K_{c}$ was reduced accordingly for the use of polyethylene mulch. However, the calculated $0.5 \times$ ET treatment provided optimum yields in all growing seasons (except Spring 2010) and were even numerically greater in seasons where there were no significant differences in calculated irrigation treatments (Fall 2010 and Fall 2011). Applying $0.5 \times$ ET rate of irrigation accompanied by the use of a tensiometer, with an optimal reading of $-40 \mathrm{kPa}$, will supply sufficient irrigation and provide an in situ measurement of soil water tension to monitor and make adjustments in unseasonable growing seasons. This recommendation is similar to findings by Locascio and Smajstrla (1996) where greatest marketable tomato yields were obtained with $0.75 \times \mathrm{ET}$ and was similar to yields obtained using a tensiometer to schedule irrigation.
Additionally, a tensiometer set point of $-40 \mathrm{kPa}$ agrees with Coolong et al. (2011) who found a dual-tensiometersystem set at $-45 /-40 \mathrm{kPa}$ used a minimal amount of water while maintaining yields compared with other tensiometer set points.

Petiole sap $\mathrm{NO}_{3}-\mathrm{N}$. In Spring $2009,1.0 \times$ ET had significantly higher petiole sap $\mathrm{NO}_{3}-\mathrm{N}$ concentrations than $0.5 \times$ ET $[792$ and 501 ppm $\mathrm{NO}_{3}-\mathrm{N}$, respectively $(P=0.07$, $\left.\left.\mathrm{LSD}_{0.10}=196\right)\right] ;$ while $1.5 \times \mathrm{ET}(648$ ppm $\mathrm{NO}_{3}-\mathrm{N}$ ) was not significantly different from either $1.0 \times \mathrm{ET}$ or $0.5 \times$ ET. Although $0.5 \times$ ET was significantly lower than $1.0 \times \mathrm{ET}$, it still falls in the sufficiency range of 400 to 600 ppm $\mathrm{NO}_{3}-\mathrm{N}$ (Hochmuth, 1994). In all subsequent seasons, there were no significant differences in petiole sap $\mathrm{NO}_{3}-\mathrm{N}$ concentrations between treatments. Generally, irrigation did not influence petiole sap $\mathrm{NO}_{3}-\mathrm{N}$, as sufficient $\mathrm{N}$ concentrations were present. Additionally, season averages consistently fell above the suggested sufficiency concentration range of 400 to 600 ppm $\mathrm{NO}_{3}-\mathrm{N}$ (Hochmuth, 1994). Hochmuth (1994) sufficiency petiole sap $\mathrm{NO}_{3}-\mathrm{N}$ concentrations were based on all $\mathrm{N}$ fertilizer being applied preplant. This study suggests the biweekly application of $\mathrm{N}$ fertilizer via fertigation throughout the growing season was the reason for our elevated petiole sap $\mathrm{NO}_{3}-\mathrm{N}$ concentrations.

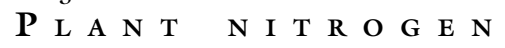
CONCENTRATION. Nitrogen concentrations in plant material differed significantly in one growing season: Spring 2010. Treatments $0.0 \times \mathrm{ET}$ and $0.5 \times$ ET had significantly more $\mathrm{N}$ per unit weight of plant material than all other treatments (33.71 and 30.81 $\mathrm{g} \cdot \mathrm{kg}^{-1} \mathrm{~N}$, respectively). Treatments $2.0 \times$ ET and Tens-40 had significantly less $\mathrm{N}$ per unit weight of plant material than all other treatments. No significant differences were observed in subsequent growing seasons. Averages for Spring 2009, Fall 2009, Fall 2010, Spring 2011, and Fall 2011 were $23.67,35.29,37.00$, 26.25 , and $38.59 \mathrm{~g} \cdot \mathrm{kg}^{-1} \mathrm{~N}$, respectively. According to standard values for tissue analysis for Florida (Hochmuth et al., 2004), our plant tissue analysis tested mainly in adequate (20 to 30 $\left.\mathrm{g} \cdot \mathrm{kg}^{-1} \mathrm{~N}\right)$ and high $\left(>30 \mathrm{~g} \cdot \mathrm{kg}^{-1} \mathrm{~N}\right)$ status levels for harvest period sampling. The lack of significant differences between treatments and adequate and high plant tissue status levels show that irrigation (neither shortages nor excess) impacted $\mathrm{N}$ concentration in plant material.

Plant $\mathrm{N}$ uptake (leaves and stems) showed no significant differences in any growing season. Irrigation did not influence total $\mathrm{N}$ uptake in the plant. Averages for Spring 2009, Fall 2009, Spring 2010, Fall 2010, Spring 2011, and Fall 2011 were $47.35,119.75,73.63,74.78$, 62.18 , and $99.54 \mathrm{lb} /$ acre $\mathrm{N}$, respectively. Zotarelli et al. (2009a) observed plant $\mathrm{N}$ uptake (leaves and stems) accumulations of 33.9, 43.6, and $53.5 \mathrm{~kg} \cdot \mathrm{ha}^{-1} \mathrm{~N}$ in spring tomato studies conducted in Florida fertilized with $176 \mathrm{~kg} \cdot \mathrm{ha}^{-1} \mathrm{~N}$. Our fall season plant $\mathrm{N}$ uptake values are larger than those found by Zotarelli et al. (2009a) and may be due to larger vegetative growth and less fruit set in these seasons.

F R U I T N I T R O G E N CONCENTRATION. Nitrogen concentrations in fruit were significantly different between treatments in one growing season: Fall 2010. Treatment Tens-40 had the largest fruit $\mathrm{N}$ concentration and was similar to treatments $1.5 \times \mathrm{ET}$, Tens-20, and Tens-60. No significant differences were observed in subsequent growing seasons. Averages for Spring 2009, Fall 2009, Spring 2010, Spring 2011, and Fall 2011 were $42.07,51.88,46.72,46.07$, and $52.33 \mathrm{~g} \cdot \mathrm{kg}^{-1} \mathrm{~N}$, respectively.

As expected, significant differences in fruit $\mathrm{N}$ uptake (Table 3 ) paralleled growing seasons with significant differences in marketable yield (Table 2). In Spring 2009, $0.5 \times$ ET and $1.0 \times$ ET had significantly greater fruit $\mathrm{N}$ uptake than $1.5 \times \mathrm{ET}$. In Fall $2009,0.5 \times$ ET and Tens-40 had significantly more fruit $\mathrm{N}$ uptake than other treatments. In Spring $2010,1.5 \times \mathrm{ET}, 2.0 \times \mathrm{ET}$, and Tens-40 had significantly more fruit $\mathrm{N}$ uptake than all other treatments while $0.0 \times \mathrm{ET}$ was significantly lower than all other treatments. In Spring $2011,0.0 \times$ ET was significantly lower than all other treatments. There were no significant differences found in Fall 2010 and Fall 2011. Fruit N uptake for all seasons ranged from 47.50 to $206.34 \mathrm{lb} /$ acre $\mathrm{N}$. This uptake range showed that $24 \%$ to $103 \%$ of the fertilizer applied (200 $\mathrm{lb} /$ acre N) left the farm after harvest. In addition, most fruit $\mathrm{N}$ uptake 
Table 3. Total nitrogen uptake in fruit biomass for fresh market tomato plants grown on a Bojac sandy loam soil in 2009, 2010, and 2011.

\begin{tabular}{|c|c|c|c|c|c|c|}
\hline \multirow[b]{3}{*}{ Treatment $^{\mathrm{z}}$} & \multicolumn{2}{|c|}{2009} & \multicolumn{2}{|c|}{2010} & \multicolumn{2}{|c|}{2011} \\
\hline & Spring & Fall & Spring & Fall & Spring & Fall \\
\hline & \multicolumn{6}{|c|}{ Total nitrogen uptake $(\mathrm{lb} / \mathrm{acre})^{\mathrm{y}}$} \\
\hline $0.0 \times \mathrm{ET}$ & - & $112.97 \mathrm{c}$ & $47.50 \mathrm{~d}$ & $103.87 \mathrm{NS}$ & $106.63 \mathrm{~b}$ & $136.90 \mathrm{NS}$ \\
\hline $0.5 \times \mathrm{ET}$ & $151.12 \mathrm{a}^{\mathrm{x}}$ & $145.48 \mathrm{ab}$ & $105.05 \mathrm{c}$ & 119.43 & $189.85 \mathrm{a}$ & 116.00 \\
\hline $1.0 \times \mathrm{ET}$ & $142.59 \mathrm{a}$ & $115.68 \mathrm{c}$ & $125.19 \mathrm{bc}$ & 88.47 & $184.29 \mathrm{a}$ & 111.65 \\
\hline $1.5 \times \mathrm{ET}$ & $100.62 \mathrm{~b}$ & $122.66 \mathrm{bc}$ & $182.22 \mathrm{a}$ & 87.29 & $178.24 \mathrm{a}$ & 117.54 \\
\hline $2.0 \times \mathrm{ET}$ & - & $118.82 \mathrm{bc}$ & $167.27 \mathrm{a}$ & 83.06 & $164.15 \mathrm{a}$ & 126.32 \\
\hline Tens-20 & - & - & $127.88 \mathrm{bc}$ & 115.50 & $206.34 \mathrm{a}$ & 143.21 \\
\hline Tens-40 & - & $160.13 \mathrm{a}$ & $162.26 \mathrm{a}$ & 110.62 & $200.56 \mathrm{a}$ & 116.57 \\
\hline Tens-60 & - & - & $134.51 \mathrm{~b}$ & 112.63 & $200.76 \mathrm{a}$ & 143.64 \\
\hline$P$ value & 0.02 & 0.05 & $<0.01$ & 0.15 & 0.05 & 0.16 \\
\hline
\end{tabular}

${ }^{\mathrm{z}} \mathrm{ET}=$ evapotranspiration; Tens $=$ tensiometer treatments set at $-20,-40$, and $-60 \mathrm{kPa}$, respectively; $1 \mathrm{kPa}=1 \mathrm{cbar}$. ${ }^{y} 1 \mathrm{lb} /$ acre $=1.1209 \mathrm{~kg} \cdot \mathrm{ha}^{-1}$.

${ }^{\mathrm{x}}$ Means followed by the same letter, within column, are not significantly different $(P<0.10)$ by Student's $t$ least significant difference test; NS = not significantly different.

Table 4. Nitrate-nitrogen concentrations of $2 \mathrm{M}$ potassium chloride-extracted soil sampled at depth after tomato growing season on a Bojac sandy loam soil in 2009, 2010, and 2011 .

\begin{tabular}{|c|c|c|c|c|c|c|}
\hline \multirow[b]{3}{*}{ Treatment $^{\mathrm{z}}$} & \multicolumn{2}{|c|}{2009} & \multicolumn{2}{|c|}{2010} & \multicolumn{2}{|c|}{2011} \\
\hline & Spring & Fall & Spring & Fall & Spring & Fall \\
\hline & \multicolumn{6}{|c|}{ Nitrate-nitrogen concn $\left(\mathrm{mg} \cdot \mathrm{kg}^{-1} \text { soil }\right)^{\mathrm{y}}$} \\
\hline \multicolumn{7}{|c|}{0 to 10 -inch depth ${ }^{y}$} \\
\hline $0.0 \times \mathrm{ET}$ & - & $3.68 \mathrm{NS}$ & $12.57 \mathrm{a}$ & $9.17 \mathrm{a}$ & $6.34 \mathrm{a}$ & $6.65 \mathrm{a}$ \\
\hline $0.5 \times \mathrm{ET}$ & $0.33 \mathrm{NS}^{\mathrm{x}}$ & 1.85 & $6.02 \mathrm{bc}$ & $4.74 \mathrm{~b}$ & $6.96 \mathrm{a}$ & $4.92 \mathrm{ab}$ \\
\hline $1.0 \times \mathrm{ET}$ & 0.29 & 1.83 & $10.21 \mathrm{ab}$ & $2.28 \mathrm{c}$ & $2.31 \mathrm{~b}$ & $4.06 \mathrm{bc}$ \\
\hline $1.5 \times \mathrm{ET}$ & 0.26 & 0.87 & $3.94 \mathrm{c}$ & $3.83 \mathrm{bc}$ & $2.63 \mathrm{~b}$ & $2.40 \mathrm{~cd}$ \\
\hline $2.0 \times \mathrm{ET}$ & - & 1.01 & $2.32 \mathrm{c}$ & $3.40 \mathrm{bc}$ & $2.16 \mathrm{~b}$ & $1.83 \mathrm{~cd}$ \\
\hline Tens-20 & - & - & $5.14 \mathrm{bc}$ & $2.21 \mathrm{c}$ & $1.83 \mathrm{~b}$ & $3.34 \mathrm{bcc}$ \\
\hline Tens-40 & - & 1.18 & $9.72 \mathrm{ab}$ & $3.72 \mathrm{bc}$ & $3.85 \mathrm{~b}$ & $1.42 \mathrm{~d}$ \\
\hline Tens-60 & - & - & $13.70 \mathrm{a}$ & $2.98 \mathrm{bc}$ & $3.21 \mathrm{~b}$ & $5.68 \mathrm{ab}$ \\
\hline$P$ value & 0.91 & 0.27 & 0.01 & $<0.01$ & 0.01 & 0.01 \\
\hline \multicolumn{7}{|c|}{10 to 20 -inch depth } \\
\hline $0.0 \times \mathrm{ET}$ & - & $2.25 \mathrm{NS}$ & $9.46 \mathrm{a}$ & $3.56 \mathrm{a}$ & $3.81 \mathrm{NS}$ & $0.79 \mathrm{NS}$ \\
\hline $0.5 \times \mathrm{ET}$ & $0.75 \mathrm{NS}$ & 1.00 & $6.05 \mathrm{ab}$ & $2.99 \mathrm{ab}$ & 3.39 & 1.59 \\
\hline $1.0 \times \mathrm{ET}$ & 0.86 & 0.64 & $4.27 \mathrm{bc}$ & $2.16 \mathrm{c}$ & 1.88 & 1.79 \\
\hline $1.5 \times \mathrm{ET}$ & 1.10 & 0.72 & $1.20 \mathrm{c}$ & $2.20 \mathrm{c}$ & 3.18 & 1.46 \\
\hline $2.0 \times \mathrm{ET}$ & - & 2.30 & $0.97 \mathrm{c}$ & $1.83 \mathrm{c}$ & 1.26 & 1.61 \\
\hline Tens-20 & - & - & $3.50 \mathrm{bc}$ & $1.93 \mathrm{c}$ & 4.77 & 1.03 \\
\hline Tens-40 & - & 0.70 & $4.89 \mathrm{bc}$ & $2.17 \mathrm{c}$ & 4.23 & 0.57 \\
\hline Tens-60 & - & - & $4.83 \mathrm{bc}$ & $2.39 \mathrm{bc}$ & 2.53 & 1.32 \\
\hline$P$ value & 0.36 & 0.40 & 0.07 & 0.02 & 0.77 & 0.12 \\
\hline \multicolumn{7}{|c|}{20 to 30 -inch depth } \\
\hline $0.0 \times \mathrm{ET}$ & - & $1.02 \mathrm{NS}$ & $2.76 \mathrm{bc}$ & $1.24 \mathrm{NS}$ & $1.93 \mathrm{NS}$ & $0.55 \mathrm{NS}$ \\
\hline $0.5 \times \mathrm{ET}$ & $0.48 \mathrm{~b}$ & 1.02 & $2.49 \mathrm{cb}$ & 1.29 & 1.99 & 0.87 \\
\hline $1.0 \times \mathrm{ET}$ & $0.57 \mathrm{~b}$ & 0.78 & $3.56 \mathrm{ab}$ & 1.13 & 1.58 & 1.21 \\
\hline $1.5 \times \mathrm{ET}$ & $1.13 \mathrm{a}$ & 0.69 & $1.08 \mathrm{c}$ & 0.92 & 3.80 & 0.89 \\
\hline $2.0 \times \mathrm{ET}$ & - & 0.90 & $1.27 \mathrm{c}$ & 0.91 & 1.41 & 0.94 \\
\hline Tens-20 & - & - & $1.68 \mathrm{bc}$ & 1.19 & 1.23 & 0.54 \\
\hline Tens-40 & - & 0.45 & $1.19 \mathrm{c}$ & 1.38 & 2.52 & 0.44 \\
\hline Tens-60 & - & - & $4.91 \mathrm{a}$ & 1.57 & 1.17 & 0.52 \\
\hline$P$ value & 0.04 & 0.17 & 0.04 & 0.66 & 0.67 & 0.30 \\
\hline
\end{tabular}

${ }^{\mathrm{z}} \mathrm{ET}=$ evapotranspiration; Tens $=$ tensiometer treatments set at $-20,-40$, and $-60 \mathrm{kPa}$, respectively; $1 \mathrm{kPa}=1 \mathrm{cbar}$. ${ }^{y} 1 \mathrm{mg} \cdot \mathrm{kg}^{-1}=1 \mathrm{ppm} ; 1$ inch $=2.54 \mathrm{~cm}$.

'Means followed by the same letter, within column, are not significantly different $(P<0.10)$ by Student's $t$ least significant difference test; NS = not significantly different. resulted in $>50 \%(100 \mathrm{lb} /$ acre $\mathrm{N})$ capture of $\mathrm{N}$ application. Zotarelli et al. (2009a) observed fruit $\mathrm{N}$ accumulations of $31.2,79.3$, and 108.2 $\mathrm{kg} \cdot \mathrm{ha}^{-1} \mathrm{~N}$ in three seasons of tomato fertilized with $220 \mathrm{~kg} \cdot \mathrm{ha}^{-1} \mathrm{~N}$ ( $14 \%$ to $48 \%$ ). Scholberg et al. (2000) found total $\mathrm{N}$ accumulation of well managed tomato was $140-200 \mathrm{~kg} \cdot \mathrm{ha}^{-1} \mathrm{~N}$ with roughly $70 \%$ of this amount accumulating in the fruit (98 to 140 $\mathrm{kg} \cdot \mathrm{ha}^{-1} \mathrm{~N}$ ). The sum of our plant $\mathrm{N}$ uptake and fruit $\mathrm{N}$ uptake accounted for a large amount of the $\mathrm{N}$ fertilizer applied (68\% to $151 \%)$, and in many treatments, resulted in a FNUE greater than $100 \%$. This large FNUE suggests an additional source of $\mathrm{N}$ might be contributing to the system. Irrigation water was tested for inorganic $\mathrm{N}$ and resulted in $\approx 0.036$ $\mathrm{mg} \cdot \mathrm{L}^{-1} \quad \mathrm{NO}_{3}-\mathrm{N}$ and $0.43 \mathrm{mg} \cdot \mathrm{L}^{-1}$ $\mathrm{NH}_{3}-\mathrm{N}$. Applications of $1.0 \times \mathrm{ET}$ at peak season (6245 gal/acre per day), irrigation water was applying 0.002 $\mathrm{lb} /$ acre per day $\mathrm{NO}_{3}-\mathrm{N}$ and 0.022 $\mathrm{lb} /$ acre per day $\mathrm{NH}_{3}-\mathrm{N}(\approx 0.09 \mathrm{lb} /$ acre $\mathrm{NO}_{3}-\mathrm{N}$ and $1.07 \mathrm{lb} /$ acre $\mathrm{NH}_{3}{ }^{-}$ $\mathrm{N}$ over the growing season). An additional possible $\mathrm{N}$ contribution to the system is high levels of $\mathrm{N}$ in the groundwater. Samples collected in shallow wells (4-ft depth) in April and May 2012 contained $\mathrm{NO}_{3}-\mathrm{N}$ concentrations $\approx 20 \mathrm{mg} \cdot \mathrm{L}^{-1} \mathrm{NO}_{3}-\mathrm{N}$.

SoIL SAMPLES. The majority of significant differences between treatments for residual soil $\mathrm{NO}_{3}-\mathrm{N}$ (Table 4 ) were seen at shallow sample depths (0 to 10 inches). Significant differences between treatments in Spring 2009 were only seen at 20 to 30 -inch depth, where $1.5 \times$ ET had significantly greater concentrations of $\mathrm{NO}_{3}-$ $\mathrm{N}$ than $0.5 \times \mathrm{ET}$ and $1.0 \times \mathrm{ET}$. There were no significant differences between treatments at the three sampled depths in Fall 2009. In the unseasonably hot and dry season of Spring 2010, there were significant differences between treatments in all sampled depths. At 0 to 10 - and 20 to 30 -inch depths, $0.0 \times$ ET had greater concentrations of $\mathrm{NO}_{3}-\mathrm{N}$ compared with other calculated irrigation treatments. Tens-60, the least irrigated tensiometer treatment, was similar in $\mathrm{NO}_{3}-\mathrm{N}$ concentration to $0.0 \times \mathrm{ET}$ at 0 to 10 inch depth, and contained greater concentrations of $\mathrm{NO}_{3}-\mathrm{N}$ at 20 to 30 inches than other treatments in Spring 2010. Being such a hot and dry season, this study suggests there was not 
enough water applied to treatments $0.0 \times$ ET and Tens-60 to optimize yields (Table 2), and therefore, residual $\mathrm{NO}_{3}-\mathrm{N}$ was greater in those treatments. In Fall 2010, significant differences between treatments were observed to 20 inches. As seen in Spring 2010, $0.0 \times$ ET contained significantly more soil $\mathrm{NO}_{3}-\mathrm{N}$ than other treatments; however, yields were not significantly different between treatments in Fall 2010. In Spring 2011, and Fall 2011, there were significant differences between treatments in the shallow sampled depth (0 to 10 inches); however, there were no differences at the lower depths (10 to 20 - and 20 to 30 -inch depths). Generally, as seen in Spring 2010, $0.0 \times$ ET had more soil $\mathrm{NO}_{3}-\mathrm{N}$ than other treatments and was statistically similar to $0.5 \times$ ET in Spring 2011 and Fall 2011. A trend of less soil $\mathrm{NO}_{3}-\mathrm{N}$ in $0.5 \times \mathrm{ET}$ vs. $0.0 \times \mathrm{ET}$ was seen in Fall 2009, Spring 2010, Fall 2010, and Fall 2011. The numerically lower concentrations of residual soil $\mathrm{NO}_{3}-\mathrm{N}$ in $0.5 \times$ ET vs. $0.0 \times \mathrm{ET}$ follows numeric yield increases between the treatments in Fall 2009, Spring 2010, and Fall 2010. This observation was also reported in Locascio and Smajstrla (1996) who observed greater inorganic $\mathrm{N}\left(\mathrm{NO}_{3}-\mathrm{N}+\mathrm{NH}_{4}-\mathrm{N}\right)(0$ to 6 inches) (20 and $\left.80 \mathrm{mg} \cdot \mathrm{kg}^{-1} \mathrm{~N}\right)$ in a 0 water treatment compared with all other irrigated treatments $(0.25 \times \mathrm{ET}$ to $1.0 \times \mathrm{ET})\left(<10 \mathrm{mg} \cdot \mathrm{kg}^{-1} \mathrm{~N}\right)$ including a tensiometer treatment in two growing seasons. Additionally, the irrigated treatments resulted in significantly greater marketable yields. A residual concentration of $10 \mathrm{mg} \cdot \mathrm{kg}^{-1}$ $\mathrm{NO}_{3}-\mathrm{N}$ equates to $\approx 20 \mathrm{lb} /$ acre $\mathrm{NO}_{3}{ }^{-}$ $\mathrm{N}$ in 6 inches of soil. Concentrations up to $13.4 \mathrm{mg} \cdot \mathrm{kg}^{-1} \mathrm{NO}_{3}-\mathrm{N}$ were found in the Tens- 60 treatment. The residual soil $\mathrm{NO}_{3}-\mathrm{N}$ has a high probability of leaching from the sandy textured soils when the polyethylene mulch is removed after the growing season if a cover crop is not implemented.

Higher calculated irrigation rates did not significantly impact residual soil $\mathrm{NO}_{3}-\mathrm{N}$ concentrations. $1.0 \times \mathrm{ET}$, $1.5 \times \mathrm{ET}$, and $2.0 \times \mathrm{ET}$ generally had statistically similar inorganic $\mathrm{N}$ concentrations in all seasons at each depth (except Spring 2010). The lack of significant differences parallels yield responses for most seasons; no significant differences were observed in yield between $1.0 \times \mathrm{ET}, 1.5 \times \mathrm{ET}$, and $2.0 \times$ ET in all seasons except Spring 2009 and Spring 2010.

\section{Conclusions}

Yield generally indicated that treatment $0.5 \times \mathrm{ET}$ was the appropriate calculated irrigation regime for optimum yields with minimal irrigation inputs. Treatment Tens-40 also provided sufficient irrigation for optimum yields. Soil data at 0 to 10 inches generally exhibited an inverse relationship to yield; greater yields resulted in less residual soil $\mathrm{NO}_{3}-\mathrm{N}$. All treatments provided sufficient $\mathrm{N}$ to plants according to plant status measurements. The use of a tensiometer as a real-time field measurement with an optimal reading of $-40 \mathrm{kPa}$ is an advantageous instrument, and can protect plants from less than adequate irrigation rates that may decrease yields.

\section{Literature cited}

Allen, R., L. Pereira, D. Raes, and M. Smith. 1998. Crop evapotranspiration Guidelines for computing crop water requirements. Irr. Drainage Paper 56. Food Agr. Organization United Nations, Rome, Italy.

Amayreh, J. and N. Al-Abed. 2005. Developing crop coefficients for field-grown tomato (Lycopersicon esculentum Mill.) under drip irrigation with black plastic mulch. Agr. Water Mgt. 73:247-254.

Angelini, R. and V. Magnifico. 2010. Il pomodoro. Coltura Cultura, Milan, Italy.

Bremner, J.M. 1996. Nitrogen - Total, p. 1085-1121. In: D.L. Sparks (ed.). Methods of soil analysis: Part 3. Soil Sci. Soc. Amer., Amer. Soc. Agron., Madison, WI.

Coolong, T., S. Surendran, and R. Warner. 2011. Evaluation of irrigation threshold and duration for tomato grown in a silt loam soil. HortTechnology 21:466-473.

Doorenbos, J. and W.O. Pruitt. 1977. Crop water requirements. Irr. Drainage Paper 24. Food Agr. Organization United Nations, Rome, Italy.

Haddadin, S.H. and I. Ghawi. 1983. Effect of plastic mulches on soil water conservation and soil temperature in field grown tomato in the Jordan Valley. Dirasat 13:25-34.

Hochmuth, G.J. 1994. Plant petiole saptesting for vegetable crops. Univ. Florida, Inst. Food Agr. Sci., Florida Coop. Ext. Serv., Hort. Sci. Dept. Cir. 1144. 24 May 2013. <http://edis.ifas.ufl.edu/cv004>.
Hochmuth, G.J., R.C. Hochmuth, and S.M. Olson. 2012. Polyethylene mulching for early vegetable production in north Florida. Univ. Florida, Inst. Food Agr. Sci., Florida Coop. Ext. Serv., Hort. Sci. Dept. Cir. 805. 24 May 2013. $<$ http://edis.ifas.ufl.edu/cv213>.

Hochmuth, G.J., D.N. Maynard, C. Vavrina, E.A. Hanlon, and E. Simonne. 2004. Plant tissue analysis and interpretation for vegetable crops in Florida. Univ. Florida, Inst. Food Agr. Sci., Florida Coop. Ext. Serv., Hort. Sci. Dept. HS964. 24 May 2013. <http://edis.ifas.ufl.edu/ pdffiles/EP/EP08100.pdf>.

Locascio, S.J. 2005. Management of irrigation for vegetables: Past, present, and future. Hort Technology 15:482-485.

Locascio, S.J. and A.G. Smajstrla. 1996. Water application scheduling by pan evaporation for drip-irrigated tomato. J. Amer. Soc. Hort. Sci. 121:63-68.

Machado, R.M.A. and M.D.G. Oliveira. 2005. Tomato root distribution, yield and fruit quality under different subsurface drip irrigation regimes and depths. Irr. Sci. 24:15-24.

Maguire, R.O. and S.E. Heckendorn. 2011. Soil test recommendations for Virginia. 24 May 2013. <http://www.soiltest.vt.edu/ $\mathrm{PDF} /$ recommendation-guidebook.pdf $>$.

Mulvaney, R.L. 1996. Nitrogen - inorganic forms, p. 1123-1184. In: D.L. Sparks (ed.). Methods of soil analysis. Part 3. Soil Sci. Soc. Amer., Amer. Soc. of Agron., Madison, WI.

Oliveira, M.D.G., A.M. Calado, and C.A.M. Portas. 1996. Tomato root distribution under drip irrigation. J. Amer. Soc. Hort. Sci. 121:644-648.

Ozores-Hampton, M., E. Simonne, F. Roka, K. Morgan, S. Sargent, C. Snodgrass, and E. McAvoy. 2012. Nitrogen rates effects on the yield, nutritional status, fruit quality, and profitability of tomato grown in the spring with subsurface irrigation. HortScience 47:1129-1135.

Scholberg, J., B.L. McNeal, K.J. Boote, J.W. Jones, S.J. Locascio, and S.M. Olson. 2000. Nitrogen stress effects on growth and nitrogen accumulation by fieldgrown tomato. Agron. J. 92:159-167.

Smajstrla, A.G., B.J. Boman, D.Z. Haman, F.T. Izuno, D.J. Pitts, and F.S. Zazueta. 1997. Basic irrigation scheduling in Florida. 24 May 2013. <http://itc.tamu.edu/ AE11100.pdf>.

Southeast Regional Climate Center. 2007. Historical climate summaries for Virginia. 24 May 2013. <http://www. sercc.com/cgi-bin/sercc/cliMAIN. pl?va6475>. 
Stanley, C.D. and G.A. Clark. 2004. Water requirements for drip-irrigated tomato production in southwest Florida. 24 May 2013. <http://edis.ifas.ufl.edu/ pdffiles/SS/SS43200.pdf $>$.

U.S. Department of Agriculture. 1991. United States standards for grades of fresh tomatoes. 24 May 2013. <http://www.ams. usda.gov $/$ AMSvl $.0 /$ getfile? dDocName $=$ STELPRDC5050331>.

U.S. Department of Agriculture. 2002. Bojac series. 24 May 2013. <https://soilseries.sc. egov.usda.gov/OSD_Docs/B/BOJAC. html>.
U.S. Department of Agriculture. 2013. Quick Stats. 24 May 2013. <http:// quickstats.nass.usda.gov/>.

Wilson, H.P., T.P. Kuhar, S.L. Rideout, J.H. Freeman, M.S. Reiter, R.A. Straw, T.E. Hines, C.M. Waldenmaier, H.B. Doughty, and U.T. Deitch. 2012. Commercial vegetable production recommendations - Virginia. Virginia Coop. Ext., Blacksburg, VA.

Zotarelli, L., M.D. Dukes, J.M. Scholberg, R. Munoz-Carpena, and J. Icerman. 2009a.
Tomato nitrogen accumulation and fertilizer use efficiency on a sandy soil, as affected by nitrogen rate and irrigation scheduling. Agr. Water Mgt. 96:1247-1258.

Zotarelli, L., J.M. Scholberg, M.D. Dukes, R. Munoz-Carpena, and J. Icerman. 2009b. Tomato yield, biomass accumulation, root distribution and irrigation water use efficiency on a sandy soil, as affected by nitrogen rate and irrigation scheduling. Agr. Water Mgt. 96:23-34. 